\title{
Transitional Dynamics with Endogenous Control Variables
}

\author{
Thomas M. Steger*
}

\section{INTRODUCTION}

The issue of 'convergence' represents one of the big topics within current economic literature (PRITCHETT, 1996). Initially, the question was simply whether poor countries are catching up with rich countries, i. e. whether there is convergence in per capita incomes. After having recognised that unconditional convergence is not taking place, the theoretical and empirical literature has centred around the conditional convergence hypothesis of the neoclassical growth model. This discussion gave rise to a coherent framework which comprises theoretical concepts and empirical methods. The widely employed method of crosssectional conditional convergence regression is crucially based on the concept of control variables, which are assumed to proxy the balanced-growth path. On account of the definition of the balanced-growth path, the control variables are usually considered as being constant in the course of economic development. However, there are strong theoretical arguments and solid empirical support for the view that at least a subset of the control variables, like the investment rates in physical and human capital and the rate of population growth, varies systematically with the level of per capita income. The explicit consideration of endogenous control variables has two important consequences. The first is purely econometric and concerns the choice of the appropriate estimation procedure in order to obtain unbiased and consistent coefficient estimates. The second concerns the theoretical interpretation of the conditional convergence results. Accordingly, the variation of some of the control variables with the level and the growth rate of per capita income contains important information about the transition to the balanced-growth equilibrium rather than information about the balanced-growth equilibrium itself. In order to exploit this information the coefficients of the control variables from the conditional convergence regression can be combined with the corresponding elasticities of the control variables with respect to per capita income. The resulting expression describes the change in the growth rate of per capita income caused by an increase in the level of per capita income while accounting for the endogenous variation of the control variables. In other words, this procedure enables the identification of several mechanisms of conditional $\beta$-convergence and $\beta$-divergence.

This paper is organised as follows: Section 2 offers a selective overview of the crosssectional convergence debate, including a theoretical discussion of structural conver-

Department of Economic Policy, University of Ulm, Germany, e-mail: steger@mathematik.uniulm.de. I would like to thank Martin Bohl for helpful comments and suggestions. Of course, the usual disclaimers apply. Support from the Friedrich-Naumann-Foundation is gratefully acknowledged. 
gence equations and a discussion of some methodological issues. Section 3 contains a cross-sectional convergence analysis which focuses explicitly on the endogeneity of the control variables. Finally, Section 4 presents a summary and conclusion.

\section{THE CONVERGENCE DEBATE: A SELECTIVE OVERVIEW}

\subsection{Structural convergence equations}

This section demonstrates concisely the derivation of structural convergence equations and discusses their main observable implications. Subsequently, the connection between structural convergence equations and convergence or growth regressions is illustrated. ${ }^{1}$ For this purpose, consider at first the following ordinary autonomous differential equation $\dot{x}(t)=F[x(t)]$, which is assumed to possess an equilibrium defined by $F\left(x^{*}\right)=0$. In the neighbourhood of this stationary point the rate or speed of convergence of $x(t)$ can be determined by means of a first-order Taylor approximation around $x^{*}$ (e. g. RoMER, 1996):

$$
\dot{x}(t) \cong F\left(x^{*}\right)+F^{\prime}\left(x^{*}\right) \cdot\left[x(t)-x^{*}\right] .
$$

By noting that by definition $F\left(x^{*}\right)=0$, the previous equation can be written as follows:

$$
\dot{x}(t) \cong-\lambda\left[x(t)-x^{*}\right] \quad \text { with } \lambda \equiv-F^{\prime}\left(x^{*}\right) .
$$

The coefficient $\lambda$ describes the (instantaneous) rate of convergence. As a result of the linearisation of the original differential equation, the variable $x(t)$ converges at a constant rate to its equilibrium value.

Because the theoretical and empirical literature is almost exclusively based on logarithmic variables, it is worth noting that the preceding result equally holds for the logarithm of $x(t)$ :

$$
\frac{d}{d t} \ln [x(t)] \cong-\lambda\left\{\ln [x(t)]-\ln \left(x^{*}\right)\right\} \quad \text { with } \quad \lambda \equiv-F^{\prime}\left(x^{*}\right) .
$$

The structural convergence equation is usually derived from the neoclassical model of growth. In this case, the analogue of the preceding equation reads as follows:

$$
\frac{d}{d t} \ln [\hat{k}(t)] \cong-\lambda\left\{\ln [\hat{k}(t)]-\ln \left(\hat{k}^{*}\right)\right\}
$$

with

$$
\lambda \equiv\left[1-\alpha\left(\hat{k}^{*}\right)\right] \cdot(n+\delta+x)>0
$$

1. The term 'structural convergence equation' denotes those convergence equations which are derived from an explicit growth model (DE LA FUENTE, 1997). Moreover, the expressions 'convergence regressions' and 'growth regressions' are used as synonyms in the literature; however the term growth regressions should not be confused with growth accounting regressions (TEMPLE, 1999). 
where $\hat{k}$ denotes the stock of capital per effective units of labour, $\alpha\left(\hat{k}^{*}\right)$ the partial elasticity of output with respect to capital evaluated at equilibrium, $n$ the growth rate of labour, $\delta$ the depreciation rate of capital, and $x$ the rate of technical progress, respectively.

The solution to this linear differential equation is given by:

$$
\ln [\hat{k}(t)]-\ln \left(\hat{k}^{*}\right) \cong\left\{\ln [\hat{k}(0)]-\ln \left(\hat{k}^{*}\right)\right\} e^{-\lambda \cdot t} .
$$

It can be shown that locally around the dynamic equilibrium income per effective units of labour, $\hat{y}$, approaches $\hat{y}^{*}$ at the same rate as $\hat{k}$ approaches $\hat{k}^{*}$ (e. g. DURLAUF and QUAH, 1998):

$$
\ln [\hat{y}(t)]-\ln \left(\hat{y}^{*}\right) \cong\left\{\ln [\hat{y}(0)]-\ln \left(\hat{y}^{*}\right)\right\} e^{-\lambda \cdot t} .
$$

Because the variable $\hat{y}$ is not observable, the preceding equation has to be expressed in terms of variables which are observable in the real world. By recalling that $y=\hat{y} A$, equation (6) can be written:

$$
\ln [y(t)]=\ln [A(0)]+x t+\ln \left[\hat{y}^{*}\right]+\left\{\ln [y(0)]-\left[\ln \left[\hat{y}^{*}\right]+\ln [A(0)]\right]\right\} e^{-\lambda \cdot t} .
$$

From equation (7) the average growth rate of per capita income over some time interval $[0, t]$ can be expressed as follows:

$$
\gamma_{0, t} \equiv \frac{\ln [y(t)]-\ln [y(0)]}{t}=x+\frac{1-e^{-\lambda \cdot t}}{t}\left\{\ln [A(0)]+\ln \left[\hat{y}^{*}\right]\right\}-\frac{1-e^{-\lambda \cdot t}}{t} \ln [y(0)] .
$$

The preceding equation is taken to be one the main observable implications of the neoclassical growth model. For any fixed time interval $[0, t]$ the average growth rate consists additively of several constant components which contain information on balanced-growth dynamics [the first two terms on the right-hand side of (8)] and on transitional dynamics [the last term on the right-hand side of (8)]. Now, if a cross-section of countries over a fixed time interval is considered, equation (8) demonstrates that conditional $\beta$-convergence $(\lambda>0)$ implies a negative partial correlation between the average annual growth rate and the initial level of per capita income. Expressed formally, (8) immediately implies that $\frac{\partial \gamma_{0, t}}{\partial \ln [y(0)]}=\frac{1-e^{-\lambda \cdot t}}{t}<0$ if $\lambda>0$

The usual empirical cross-sectional growth regression stems directly from the theoretical convergence equation (8) and can be written as follows (e. g. Barro and SALA-IMARTIN, 1992):

$$
\gamma_{i, 0, t}=a_{0}-a_{1} \ln \left(y_{i, 0}\right)+\mathbf{v} \mathbf{x}_{\mathbf{i}}+\varepsilon_{i, 0, t}
$$

where $\gamma_{i, 0, t}$ denotes the average annual growth rate of per capita income over the period $[0, t]$ for country $i, a_{0}$ a positive constant, $y_{i, 0}$ the initial level of per capita income, $\mathbf{v}$ a vector of further regression coefficients, $\mathbf{x}_{\mathbf{i}}$ a vector of so-called control variables and $\varepsilon_{i, 0, t}$ an independently and identically distributed error term with mean zero, respectively. The variables in $\mathbf{x}$ are supposed to capture the determinants of the balanced-growth path. 
A vast empirical literature has identified about 50 variables which are correlated with the (average) growth rate of per capita income (e.g. Kormend and MEgUIRE, 1985 and Barro, 1991). ${ }^{2}$ The list of control variables includes, among others, the investment rates for physical and human capital, the share of government consumption in GDP, the blackmarket premium, as well as measures of political instability.

\subsection{Some methodological issues}

This section discusses some of the methodological issues which arise within the context of cross-sectional conditional convergence analyses. On this occasion three problems will be considered: (i) endogeneity of the control variables; (ii) fixed bias effects due to omitted variables; and (iii) the appropriate calculation of growth rates. ${ }^{3}$

\section{ENDOGENEITY OF THE CONTROL VARIABLES}

As has been shown in the previous section, the analysis of conditional convergence is crucially based on the approximation of the balanced-growth path. Empirically this is achieved by employing a set of control variables. On account of the definition of the balanced-growth path the control variables are required to be time invariant. However, there are strong theoretical arguments and solid empirical support for the view that at least a subset of the control variables varies systematically with the level of per capita income (CoHEN, 1992 and CASElli, Esquivel, and LeFort, 1996). The possibility of endogenous control variables causes two distinct problems whereat the first is purely econometric while the second concerns the theoretical interpretation of the conditional convergence results.

The presence of endogeneity means that some of the control variables might be determined simultaneously with the level or the growth rate of per capita income. In this case the control variables are correlated with the error term and the usual ordinary leastsquares procedure (OLS) yields biased and inconsistent estimators. For expositional convenience assume that there is only one control variable and that the 'true' structural convergence model consists of two equations:

$$
\begin{gathered}
\gamma_{i, 0, t} \equiv\left[\ln \left(y_{i, t}\right)-\ln \left(y_{i, 0}\right)\right] / t=a_{0}-a_{1} \ln \left(y_{i, 0}\right)+a_{2} \ln \left(x_{i, 0}\right)+\varepsilon_{i, 0, t} \\
\ln \left(x_{i, 0}\right)=b_{0}+b_{1} \ln \left(y_{i, 0}\right)+\nu_{i, 0}
\end{gathered}
$$

Now, within the context of empirical convergence analyses the issue of biased and inconsistent OLS estimators depends heavily on the specification of the control variable (TEM-

2. Durlauf and Quah (1998, Table 5-2) present a very comprehensive overview of the literature.

3. Additional econometric problems connected with cross-sectional convergence analyses are discussed more comprehensively in BoHL (1998) and TEMPLE (1999). 
PLE, 1999). MANKIW, Romer, and Weil (1992), for example, estimate a convergence regression similar to (10) with the control variables specified as averages over the sample period, i. e. $\bar{x}_{i}=\left(x_{i, t}+x_{i, 0}\right) 0.5$. By substituting $\bar{x}_{i}$ for $x_{i, 0}$ in (10), the above equation system becomes simultaneous and the control variable, $\bar{x}_{i}$, becomes endogenous with respect to the growth rate of per capita income. ${ }^{4}$ In order to avoid this problem other authors use the initial or lagged values of the control variables as instruments (e. g. Barro, 1991 and Barro and SALA-I-MARTIN, 1992). In this case, the above equation system demonstrates that convergence regressions like (10) originate from a recursive system of equations and therefore OLS estimators are unbiased and consistent. However, it can sensibly be questioned whether the control variables can really be considered as being constant along the transition to the balanced-growth equilibrium (KLENOW and RoDRíGUEZ-Clare, 1997). This question can, in principle, be answered on empirical or theoretical grounds. As already mentioned above, empirical evidence clearly suggests that at least the investment rates in physical and human capital and the growth rate of population vary systematically with the level of per capita income (COHEN, 1992 and Caselli, Esquivel, and Lefort, 1996). Theoretically, the constancy of the control variables along the transition path seems to represent special cases rather than the rule for the class models with sound microeconomic foundations. For example, the RAMSEYCASS-Koopmans model implies a constant investment rate only if the balanced-growth investment rate equals the intertemporal elasticity of substitution in consumption (e. $g$. Barro and SAla-I-MarTin, 1995, Chapter 2). ${ }^{5}$

The second point concerns the theoretical interpretation of the conditional convergence results. The variation of some of the control variables with income contains important information about the transition to the balanced-growth equilibrium rather than about the balanced-growth equilibrium itself. In order to illustrate this point, a general expression for the growth rate of per capita income is considered ( $\mathrm{CHO}, 1996)$ :

$$
\gamma=G\left[y, x_{1}, x_{2}(y)\right] \text {. }
$$

The conditional convergence coefficient measures merely the partial correlation between the growth rate of per capita income and the level of per capita income, i. e. $\partial \gamma / \partial y$. However, if some of the control variables vary with per capita income, the total correlation differs from this partial correlation. For the growth rate specification given in (12) the total derivative is: $d \gamma / d y=\partial \gamma / \partial y+\left(\partial \gamma / \partial x_{2}\right) \cdot\left(d x_{2} / d y\right)$. It seems that convergence investigations should consider the total correlation including the indirect effects through

4. MANKIW, Romer, and Weil (1992) acknowledge that the possible endogeneity of the control variables might cause problems and mention three reasons for the assumption that the saving rate and the rate of population growth are independent from the error term within their specification of convergence regression.

5. In contrary, there are a lot of theoretical approaches which demonstrate the endogeneity of several typical control variables. For instance, the saving rate can be shown to increase with the level of per capita income in the course of economic development if subsistence consumption is taken into consideration and several growth models imply a negative relation between the population growth rate and the level of per capita income (e. g. Becker and Barro, 1988). 
the endogenous channels of the control variables. The second component of the total derivative, i. e. $\left(\partial \gamma / \partial x_{2}\right) \cdot\left(d x_{2} / d y\right)$, clearly contains important information on the transition process and indicates whether growth tends to accelerate or decelerate in the course of economic development.

\section{AN OMITTED VARIABLE}

Equation (7), which shows the time path of the logarithm of per capita income, immediately demonstrates that the initial level of technology, $A(0)$, determines, among other variables, the intercept of the balanced-growth path. Consequently, this variable should, in principle, be included into conditional convergence regressions. However, because this variable cannot be observed directly it is usually omitted. As a result, the parameter estimates are biased provided that the omitted variable is correlated with other right-handside variables (TEMPLE, 1998). This assumption seems to be highly plausible as TeMPLE (1999, p. 15) points out: "In practice, countries that are relatively less efficient are also likely to have lower investment rates, and one can easily imagine further correlations with other right-hand-side variables." ${ }^{\prime 6}$ Because international variations in efficiency seem to be most important between different (sub-) continents, one way to account for this omitted variable problem consists in the use of regional dummy variables. TEMPLE (1998) shows that 75 per cent of the variation in initial efficiency are 'explained' by regional dummies.

\section{THE CALCULATION OF GROWTH RATES}

The third point concerns the calculation of average growth rates, which are the dependent variable in cross-country growth regressions. The usual method merely uses the figures on initial and final output for each country. However, macroeconomic shocks and business cycle effects are likely to produce deviations from the trend path of output. It therefore seems to be preferable to employ the whole time series information contained in the Summers and HeSTON (1999) data set and to estimate a trend path by regressing the whole of the logarithmic per capita income series on a constant and a time trend. On the basis of this fitted trend path in logarithmic per capita income one can easily calculate 'least-square growth rates', which are more robust with respect to short-run instabilities (TEMPLE, 1999).

6. Islam (1995) and CASElli, Esquivel, and LeFORT (1996) present evidence that the initial efficiency is indeed correlated with the regressors. 


\section{CROSS-SECTIONAL CONVERGENCE ANALYSIS}

\subsection{Procedure and data}

This section describes the procedure which will be applied as well as the definitions and sources of the data. The procedure is used to identify mechanisms of convergence and divergence and essentially follows a procedure suggested by $\mathrm{CHO}_{\mathrm{HO}}$ (1996). The conditional convergence regression is of the following form:

$$
\gamma_{i, 0, t}=a_{0}+a_{1} \ln \left(y_{i, 0}\right)+b_{j} \ln \left(\bar{x}_{j, i}\right)+\varepsilon_{i, 0, t},
$$

where $\gamma_{i, 0, t}$ denotes the average annual growth rate of per capita income for country $i$ over the sample period $[0, t], y_{i, 0}$ the initial level of per capita income for country, $i, \bar{x}_{j, i}$ the average over the sample period of the $j$-th control variable for country $i$, and $\varepsilon_{i, 0, t}$ an identically and independently distributed error term, respectively. The control variables are considered as being simultaneously determined with the level of per capita income. Consequently, the averages of the control variables over the sample period are specified as being dependent on the average level of per capita income over the sample period:

$$
\ln \left(\bar{x}_{j, i}\right)=c_{0}+c_{j} \ln \left(\bar{y}_{i}\right)+\nu_{j, i}
$$

The coefficient $c_{j}$ gives the elasticity of the average $\mathrm{j}$-th control variable with respect to average per capita income. In order to estimate the conditional convergence regression (13) consistently, a two-stage least-square procedure (TSLS) is employed. In addition, the elasticities of the control variables with respect to per capita income are estimated by applying an OLS procedure to the regression equation (14).

The underlying data set comprises 120 economies and covers the time period from 1960-85. ${ }^{7}$ Following MANKIw, RoMER, and WeIL (1992) oil-producing countries are excluded from the sample because a large part of recorded GDP for these countries represents the extraction of existing resources and one should not expect standard growth models to account for measured GDP in these countries. The various variables which are utilised within this section are shown in Table 1. In addition, this table describes the definitions of variables, their availability, and sources.

7. . More recent data are rarely available for several control variables in the case of DCs. The extension of the sample period would therefore introduce a sample selection bias. 
Table 1: Definitions of variables, availability, and sources.

\begin{tabular}{|c|c|c|c|}
\hline Variable & Definition & $\begin{array}{c}\text { Availability } \\
\text { (Number of countries) }\end{array}$ & Source \\
\hline$y$ & Real GDP per capita & annually (120) & Penn World Tables 5.6 \\
\hline$i$ & $\begin{array}{c}\text { Investment } \\
\text { share of GDP }\end{array}$ & annually (119) & Penn World Tables 5.6 \\
\hline$n$ & Population growth rate & annually (117) & Penn World Tables 5.6 \\
\hline$h$ & $\begin{array}{l}\text { Educational attainment: } \\
\text { average schooling years } \\
\text { in total population } \\
\text { over age } 25\end{array}$ & quinquennially (91) & BARRo and LEE (1994) \\
\hline$g$ & $\begin{array}{l}\text { Government } \\
\text { share of GDP }\end{array}$ & annually (120) & Penn World Tables 5.6 \\
\hline$p$ & $\begin{array}{l}\text { Measure of political } \\
\text { instability consisting } \\
\text { of assassinations per } \\
\text { million population } \\
\text { per year (ass) and the } \\
\text { number of revolutions } \\
\text { per year (rev): } \\
p=0.5 \cdot \text { ass }+0.5 \cdot \text { rev }\end{array}$ & annually (83) & BANKS (1997) \\
\hline$b$ & Black-market premium & $\begin{array}{c}\text { averages over five } \\
\text { year sub-periods (96) }\end{array}$ & BARRO and LEE (1994) \\
\hline$f$ & $\begin{array}{l}\text { Financial development } \\
\text { measured as domestic } \\
\text { credit provided by } \\
\text { banking sector as } \\
\text { share of GDP }\end{array}$ & annually (63) & World Bank (1998) \\
\hline
\end{tabular}

\footnotetext{
${ }^{a}$ This data set is referred as Summers and Heston (1999), which is basically described and discussed in Summers and Heston (1988).
}

Following TEMPLE (1998) the set of dummy variables consists of regional dummies for sub-Saharan Africa, D1, the group of industrialised countries, D2, East Asia, D3, and Latin America and the Caribbean, D4. Finally, the dependent variables of the conditional convergence regression are least-square growth rates as explained in Section 2.2.

This section extends Сно's (1996) paper in three directions: (i) The set of control variables is enlarged (see Section 3.2); (ii) the possibility of international differences in the in- 
itial level of efficiency is taken into consideration by the use of regional dummy variables; (iii) the dependent variable are least-square growth rates instead of actual growth rates.

\subsection{Endogeneity of control variables}

It has been argued in Section 2.2 that the control variables are likely to depend systematically on the level of per capita income. In this case those variables which are expected to proxy the balanced-growth path vary during the transition to the balanced-growth equilibrium. This section presents empirical evidence which illustrates the cross-country correlation between the level of per capita income and a set of widely used control variables. This set of control variables comprises the investment rate, $i$, the rate of population growth, $n$, the government share of GDP, $g$, the black-market premium on foreign exchange, $b$, a proxy for human capital, $h$, a measure of political instability, $p$, and a measure of financial development, $f$. Table 2 presents the results of the regressions of the logarithm of the various control variables on the logarithm of per capita income. The coefficients of the logarithm of per capita income represent the elasticities of the control variables under study with respect to per capita income. The signs of all elasticities are in line with theoretical expectations. In addition, all coefficients are highly significant; the $t$-values are shown in parentheses below the coefficient estimates.

Table 2: Endogenous control variables.

\begin{tabular}{ccccc}
\hline $\begin{array}{c}\text { Dependent } \\
\text { variable }\end{array}$ & Constant $^{\mathrm{a}}$ & $\ln (\bar{y})^{\mathrm{a}}$ & $R^{2}$ & Sample size \\
\hline $\ln (\bar{i})$ & -5.62 & 0.478 & 0.45 & 119 \\
& $(-14.84)$ & $(9.76)$ & & \\
$\ln (\bar{n})$ & -0.66 & -0.442 & 0.40 & 117 \\
& $(-1.70)$ & $(8.80)$ & & 120 \\
$\ln (\bar{g})$ & -0.43 & -0.175 & 0.17 & 93 \\
& $(-1.60)$ & $(-5.01)$ & & 87 \\
$\ln (1+\bar{b})$ & 1.32 & -0.143 & 0.22 & \\
& $(-5.98)$ & $(-5.04)$ & & 83 \\
$\ln (\bar{h})$ & -3.94 & 0.655 & 0.69 & \\
& $(-10.36)$ & $(13.70)$ & & \\
$\ln (1+\bar{p})$ & 0.39 & -0.040 & 0.18 & \\
& $(-5.17)$ & $(-4.18)$ & & \\
\hline
\end{tabular}




\begin{tabular}{ccccc}
\hline $\begin{array}{c}\text { Dependent } \\
\text { variable }\end{array}$ & Constant $^{\mathrm{a}}$ & $\ln (\bar{y})^{\mathrm{a}}$ & $R^{2}$ & Sample size \\
\hline $\ln (1+\bar{f})$ & -0.56 & 0.114 & 0.35 & 63 \\
& $(-3.53)$ & $(5.77)$ & & \\
\hline
\end{tabular}

${ }^{\mathrm{a}}$ The t-values are shown in brackets below the coefficient estimates.

Figure 1 shows scatter plots for the averages of the seven control variables and the average of per capita income over the sample period 1960-85. In addition, each diagram contains a log-linear regression line. The investment rate, the proxy for human capital, and the indicator of financial development appear to vary positively with the level of per capita income [Figure 1 (a), (e), and (g)], while the population growth rate, the government share of GDP, the black-market premium, and the proxy for political instability appear to vary negatively with per capita income [Figure 1 (b), (c), (d), and (f)].

Figure 1: Scatter plots for seven control variables and per capita income.
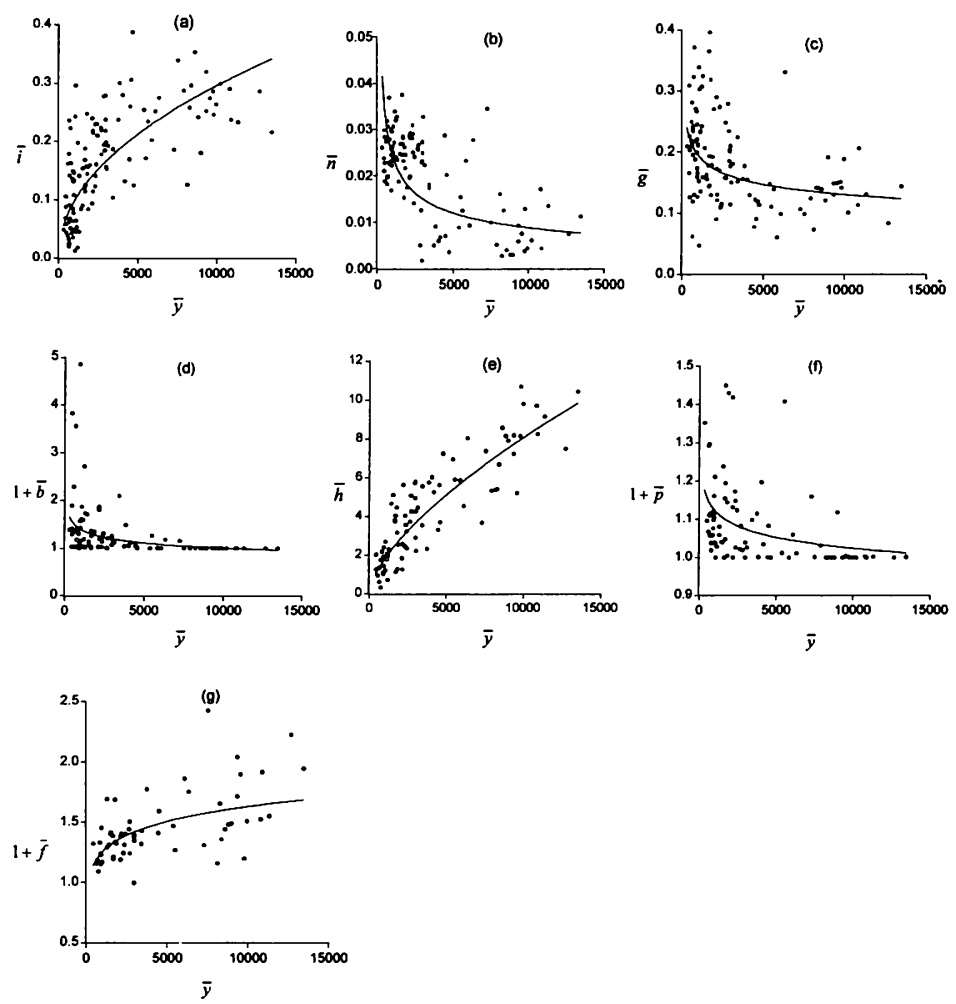
This short empirical evidence clearly indicates that the variables under study are strongly correlated with the level of per capita income. However, unless the control variables are exogenous with respect to per capita income, the OLS estimation suffers from a simultaneity problem caused by the correlation between a subset of the independent variables and the error term.

\subsection{Convergence analysis with endogenous control variables}

Table 3 shows the results of several conditional convergence regressions. The dependent variable is the average annual growth rate of per capita income 1960-85 based on the fitted values of per capita income, i. e. least-square growth rates. The first row indicates the estimation procedure which has been employed (OLS or TSLS) and the number of countries included in the sample shown in parentheses. The TSLS estimation procedure is employed because it accounts for the endogeneity of the control variables. Since the initial values of the right-hand-side variables are almost uncorrelated with the residuals from the OLS estimation, these predetermined variables are used as instruments during the first stage of the TSLS estimation. The first column shows the independent variables together with the $R^{2}$ and the implied rate of convergence, $\lambda$. The remaining columns contain the coefficient estimates together with the corresponding $t$-values shown in parentheses below each coefficient estimate.

The control variables are predominantly arranged by the number of available observations. Because the availability of data differs for the distinct control variables, the first conditional convergence regression starts with the set of those control variables for which the number of observations is comparably large, i. e. $\bar{i}, \bar{n}$, and $\bar{g}$. Every second column adds one further control variable to the conditional convergence regression. Thereby, the common sample size decreases from $116(112)$ to 45 . The use of comparably small samples is undoubtedly unsatisfactory because the data availability is higher for 'rich' countries than for 'poor' countries or, stated differently, "[l]ong-run national accounts are luxuries" (DE LoNG, 1988, p. 1141). The likely correlation between the availability of data and the level of economic development inevitably introduces a sample selection bias. For this reason, the interpretations of the next section are based on the coefficient estimates which stem from the tallest sample size. This procedure aims at reducing the inevitable sample selection bias resulting from data restrictions and therefore appears acceptable as a 'second-best strategy'. It is needless to say that the estimation results should therefore be interpreted with care. Finally, because some of the control variables are correlated with the dummy variables, each regression is reestimated by excluding the dummy variables.

\subsection{Interpretation of main findings}

First of all, most of the regressions show a comparably high $R^{2}$. The second and the fourth column of Table 3 show that the dummy variable for sub-Saharan Africa, D1, as well as the 
dummy variable for Latin America and the Caribbean, D4, are significantly negative and that the dummy variable for East Asia, D3, is significantly positive. ${ }^{8}$ For six of the eight right-hand-side variables, excluding the constant and the dummy variables, the signs are in line with theoretical expectations. The coefficient of the political-instability variable, $p$, shows the 'wrong' sign and is insignificant. The coefficient of the financial-development variable, $f$, also appears with the 'wrong' sign and is insignificant when the regional dummies are excluded. Hence, these variables are excluded from the interpretation. ${ }^{9}$

The second column of Table 3 reproduces an important result of the empirical convergence literature. The convergence coefficient which results from a conditional convergence estimation is significantly negative, the numerical value amounts to -0.00927 and the corresponding $t$-value is -3.60 . The conditional convergence hypothesis of the neoclassical growth model is therefore supported. The implied rate of convergence amounts to 1 per cent and is roughly consistent with the usual results of the cross-sectional convergence literature (e. g. De LA FuENTE, 1997). The fourth column reports the estimation results using a TSLS procedure. In this case, the estimated convergence coefficient is higher, i. e. smaller in absolute value, and amounts to -0.00646 . Accordingly, an increase in the initial level of per capita income by 1 per cent is estimated to reduce the average annual growth rate of per capita income by approximately 0.6 percentage points on average. The implied speed of convergence is 0.7 per cent. However, this interpretation crucially relies on the assumption that the other explanatory variables are held constant. In addition, this convergence effect should be interpreted carefully as representing the net effect of all unidentified convergence mechanisms, including the neoclassical convergence mechanism as well as the technological catch-up mechanism, and divergence mechanisms.

In what follows the estimation results from Table 2 are combined with the estimation results from Table 3 in order to determine numerically several mechanisms of convergence or divergence. Formally, the various coefficients of the control variables from the conditional convergence regression, $\partial \gamma / \partial \ln \left(\bar{x}_{i}\right)$, are combined with the corresponding elasticities of the control variables with respect to per capita income, $d \ln \left(\bar{x}_{i}\right) / d \ln (\bar{y})$. The resulting coefficient, i. e. $C M_{j} \equiv \frac{\partial \gamma}{\partial \ln \left(\bar{x}_{j}\right)} \cdot \frac{d \ln \left(\bar{x}_{j}\right)}{d \ln (\bar{y})}$, describes the change in the growth rate of per capita income caused by an increase in the level of per capita income by accounting for the endogenous variation of the control variables. This coefficient describes a mechanism of conditional $\beta$-convergence if $C M_{j}<0$ and a mechanism of conditional $\beta$-divergence if $C M_{j}>0$.

8. This indicates that some determinants which are relevant to growth for these groups of countries are not captured adequately by the list of right-hand-side variables. EASTERLY and LEVINE (1997), for example, analyse the meaning of ethnic diversity in sub-Saharan Africa for the process of growth.

9. The smaller the sample size, the more important is the sample selection bias discussed above. Hence, the results for political instability and financial development might be due to this kind of sample selection bias. Barro and SALA-I-MARTIN (1995, Table 12.3), for example, report a negative coefficient on political instability which is marginally significant. LEVINE and RENELT (1997, Table VII), however, find a positive and significant correlation between annual average growth and different indicators of financial development. 
Table 3: Convergence regression results

Dependent variable: average annual least-square growth rate of per capita income 1960-85.

\begin{tabular}{|c|c|c|c|c|c|c|c|c|c|c|c|c|}
\hline & $\begin{array}{l}\text { OLS } \\
(116)\end{array}$ & $\begin{array}{l}\text { OLS } \\
(116)\end{array}$ & $\begin{array}{l}\text { TSLS } \\
(112)\end{array}$ & $\begin{array}{l}\text { TSLS } \\
(112)\end{array}$ & $\begin{array}{c}\text { TSLS } \\
(90)\end{array}$ & $\begin{array}{l}\text { TSLS } \\
(90)\end{array}$ & $\begin{array}{c}\text { TSLS } \\
(75)\end{array}$ & $\begin{array}{c}\text { TSLS } \\
(75)\end{array}$ & $\begin{array}{c}\text { TSLS } \\
(61)\end{array}$ & $\begin{array}{c}\text { TSLS } \\
(61)\end{array}$ & $\begin{array}{c}\text { TSLS } \\
(45)\end{array}$ & $\begin{array}{c}\text { TSLS } \\
(45)\end{array}$ \\
\hline Constant & $\begin{array}{l}0.09723 \\
(4.77)\end{array}$ & $\begin{array}{l}0.09795 \\
(5.29)\end{array}$ & $\begin{array}{l}0.08299 \\
(3.68)\end{array}$ & $\begin{array}{l}0.06816 \\
(3.17)\end{array}$ & $\begin{array}{l}0.11910 \\
(4.29)\end{array}$ & $\begin{array}{l}0.07449 \\
(2.60)\end{array}$ & $\begin{array}{l}0.10887 \\
(4.23)\end{array}$ & $\begin{array}{l}0.08358 \\
(3.01)\end{array}$ & $\begin{array}{l}0.12269 \\
(4.97)\end{array}$ & $\begin{array}{l}0.11861 \\
(4.25)\end{array}$ & $\begin{array}{l}0.13434 \\
(3.84)\end{array}$ & $\begin{array}{l}0.14234 \\
(4.15)\end{array}$ \\
\hline $\ln [y(60)]$ & $\begin{array}{l}-0.00927 \\
(-3.60)\end{array}$ & $\begin{array}{l}-0.01025 \\
(-4.21)\end{array}$ & $\begin{array}{l}-0.00646 \\
(-2.25)\end{array}$ & $\begin{array}{l}-0.00472 \\
(-1.59)\end{array}$ & $\begin{array}{l}-0.00923 \\
(-2.72)\end{array}$ & $\begin{array}{l}-0.00595 \\
(-1.55)\end{array}$ & $\begin{array}{l}-0.01122 \\
(-3.03)\end{array}$ & $\begin{array}{l}-0.01145 \\
(-2.72)\end{array}$ & $\begin{array}{l}-0.01100 \\
(-3.06)\end{array}$ & $\begin{array}{l}-0.01492 \\
(-4.08)\end{array}$ & $\begin{array}{l}-0.01405 \\
(-3.45)\end{array}$ & $\begin{array}{l}-0.01511 \\
(-4.58)\end{array}$ \\
\hline $\ln (\bar{i})$ & $\begin{array}{l}0.01561 \\
(6.42)\end{array}$ & $\begin{array}{l}0.01973 \\
(7.68)\end{array}$ & $\begin{array}{l}0.00987 \\
(3.29)\end{array}$ & $\begin{array}{l}0.01306 \\
(4.12)\end{array}$ & $\begin{array}{l}0.00819 \\
(2.24)\end{array}$ & $\begin{array}{l}0.01245 \\
(3.02)\end{array}$ & $\begin{array}{l}0.00450 \\
(0.91)\end{array}$ & $\begin{array}{l}0.00791 \\
(1.34)\end{array}$ & $\begin{array}{l}0.01653 \\
(3.42)\end{array}$ & $\begin{array}{l}0.01571 \\
(2.61)\end{array}$ & $\begin{array}{l}0.01282 \\
(1.65)\end{array}$ & $\begin{array}{l}0.01552 \\
(1.77)\end{array}$ \\
\hline $\ln (\bar{n})$ & $\begin{array}{l}-0.00377 \\
(-1.42)\end{array}$ & $\begin{array}{l}-0.00464 \\
(-1.70)\end{array}$ & $\begin{array}{l}-0.00063 \\
(-0.17)\end{array}$ & $\begin{array}{l}-0.00057 \\
(-0.16)\end{array}$ & $\begin{array}{l}0.00349 \\
(0.84)\end{array}$ & $\begin{array}{l}0.00056 \\
(0.14)\end{array}$ & $\begin{array}{l}0.00057 \\
(0.16)\end{array}$ & $\begin{array}{l}-0.00217 \\
(-0.57)\end{array}$ & $\begin{array}{l}-0.00217 \\
(-0.78)\end{array}$ & $\begin{array}{l}-0.00429 \\
(-1.39)\end{array}$ & $\begin{array}{l}-0.00030 \\
(-0.08)\end{array}$ & $\begin{array}{l}-0.00463 \\
(-1.58)\end{array}$ \\
\hline $\ln (\bar{g})$ & $\begin{array}{l}-0.00954 \\
(-2.44)\end{array}$ & $\begin{array}{l}-0.01184 \\
(-2.87)\end{array}$ & $\begin{array}{l}-0.00624 \\
(-1.25)\end{array}$ & $\begin{array}{l}-0.00749 \\
(-1.43)\end{array}$ & $\begin{array}{l}-0.00758 \\
(-1.16)\end{array}$ & $\begin{array}{l}-0.01144 \\
(-1.67)\end{array}$ & $\begin{array}{l}-0.00904 \\
(-1.38)\end{array}$ & $\begin{array}{l}-0.01418 \\
(-2.09)\end{array}$ & $\begin{array}{l}-0.00685 \\
(-1.28)\end{array}$ & $\begin{array}{l}-0.01374 \\
(-2.44)\end{array}$ & $\begin{array}{l}-0.00231 \\
(-0.39)\end{array}$ & $\begin{array}{l}-0.00306 \\
(-0.55)\end{array}$ \\
\hline $\ln (1+\bar{b})$ & & & & & $\begin{array}{l}-0.01705 \\
(-1.56)\end{array}$ & $\begin{array}{l}-0.00002 \\
(-0.00)\end{array}$ & $\begin{array}{l}-0.02144 \\
(-1.89)\end{array}$ & $\begin{array}{l}-0.00682 \\
(-0.49)\end{array}$ & $\begin{array}{l}-0.00769 \\
(-0.89)\end{array}$ & $\begin{array}{l}-0.00343 \\
(-0.33)\end{array}$ & $\begin{array}{l}0.00483 \\
(0.31)\end{array}$ & $\begin{array}{l}-0.01564 \\
(-1.71)\end{array}$ \\
\hline $\ln (\bar{h})$ & & & & & & & $\begin{array}{l}0.00566 \\
(1.29)\end{array}$ & $\begin{array}{l}0.00736 \\
(1.42)\end{array}$ & $\begin{array}{l}0.00091 \\
(0.24)\end{array}$ & $\begin{array}{l}0.00566 \\
(1.22)\end{array}$ & $\begin{array}{l}0.00011 \\
(0.02)\end{array}$ & $\begin{array}{l}0.00416 \\
(0.76)\end{array}$ \\
\hline $\ln (1+\bar{p})$ & & & & & & & & & $\begin{array}{l}-0.00114 \\
(-0.05)\end{array}$ & $\begin{array}{l}-0.02357 \\
(-0.94)\end{array}$ & $\begin{array}{l}0.01028 \\
(0.33)\end{array}$ & $\begin{array}{l}-0.01747 \\
(-0.57)\end{array}$ \\
\hline $\ln (1+\bar{f})$ & & & & & & & & & & & $\begin{array}{l}0.00553 \\
(0.33)\end{array}$ & $\begin{array}{l}-0.00049 \\
(-0.02)\end{array}$ \\
\hline D1 & $\begin{array}{l}-0.01340 \\
(-3.37)\end{array}$ & & $\begin{array}{l}-0.01501 \\
(-3.58)\end{array}$ & & $\begin{array}{l}-0.01787 \\
(-3.74)\end{array}$ & & $\begin{array}{l}-0.01788 \\
(-3.82)\end{array}$ & & $\begin{array}{l}-0.01927 \\
(-4.08)\end{array}$ & & $\begin{array}{l}-0.02262 \\
(-0.99)\end{array}$ & \\
\hline D2 & $\begin{array}{l}-0.00474 \\
(-0.89)\end{array}$ & & $\begin{array}{l}-0.00080 \\
(-0.13)\end{array}$ & & $\begin{array}{l}0.00253 \\
(0.37)\end{array}$ & & $\begin{array}{l}-0.00335 \\
(-0.49)\end{array}$ & & $\begin{array}{l}-0.00301 \\
(-0.53)\end{array}$ & & $\begin{array}{l}0.02353 \\
(1.85)\end{array}$ & \\
\hline D3 & $\begin{array}{l}0.01874 \\
(2.80)\end{array}$ & & $\begin{array}{l}0.02288 \\
(3.19)\end{array}$ & & $\begin{array}{l}0.01759 \\
(2.18)\end{array}$ & & $\begin{array}{l}0.01406 \\
(1.76)\end{array}$ & & $\begin{array}{l}0.01373 \\
(1.96)\end{array}$ & & $\begin{array}{l}0.02815 \\
(2.84)\end{array}$ & \\
\hline D4 & $\begin{array}{l}-0.01168 \\
(-2.72)\end{array}$ & & $\begin{array}{l}-0.01090 \\
(-2.40)\end{array}$ & & $\begin{array}{l}-0.01423 \\
(-2.71)\end{array}$ & & $\begin{array}{l}-0.01586 \\
(-3.02)\end{array}$ & & $\begin{array}{l}-0.01059 \\
(-2.48)\end{array}$ & & $\begin{array}{l}0.00458 \\
(0.73)\end{array}$ & \\
\hline$R^{2}$ & 0.56 & 0.42 & 0.53 & 0.37 & 0.58 & 0.37 & 0.67 & 0.45 & 0.75 & 0.59 & 0.68 & 0.66 \\
\hline implied $\lambda$ & 0.01054 & 0.01184 & 0.00704 & 0.00502 & & & & & & & & \\
\hline
\end{tabular}


Table 3 shows that the partial correlation between the growth rate of per capita income and the investment rate amounts to 0.00987 . An increase in the investment rate by 1 per cent is estimated to increase the growth rate of per capita income by approximately 1 percentage point on average. ${ }^{10}$ Table 2 shows that the elasticity of the investment rate with respect to per capita income equals 0.478 and consequently $C M_{i} \cong 0.00987 \cdot 0.478 \cong 0.005$. This divergence mechanism can be interpreted as follows: In the course of economic development, the level of per capita income and the ability to save increase. As a consequence, the saving and investment rate rise as well, which causes the growth rate of per capita income to increase. This mechanism is statistically significant since both components of $C M_{\bar{i}}$ are highly significant. Furthermore, the magnitude of this subsistence-divergence mechanism is quantitatively comparable to the conditional convergence mechanism described above.

The 'convergence mechanism' associated with the endogenous variation of the population growth rate is $C M_{\bar{n}} \cong-0.00063 \cdot-0.442 \cong 0.0002$. Because $C M_{\bar{n}}>0$, the variation in the population growth rate represents a further divergence mechanism. However, the quantitative meaning appears to be small and the statistical significance is extremely fragile.

The partial correlation between the growth rate of per capita income and the government share of GDP together with the elasticity of the government share of GDP with respect to per capita income yield the 'convergence mechanism' associated with the government share of GDP: $C M_{\bar{g}} \cong-0.00624 \cdot-0.175 \cong 0.001$. The negative effect of the government share of GDP on growth can be interpreted as the adverse impact of non-productive government expenditures, including military expenditures, as well as the adverse impact of taxation (LEVINE and RENELT, 1992). Again, the endogenous variation of the government share of GDP establishes a further divergence mechanism.

Table 3 shows that a decreasing black-market premium is estimated to increase the growth rate of per capita income. According to Table 2, the black-market premium falls with the level of per capita income. The corresponding 'convergence mechanism' reads $C M_{\bar{b}} \cong-0.01705 \cdot-0.143 \cong 0.0024$. The black-market premium can be considered to proxy for government distortions of markets which influence the process of growth adversely (Barro and SALA-I-MAR'TIN, 1995).

With respect to the human-capital variable, the 'convergence mechanism' reads as follows: $C M_{\bar{h}} \cong 0.00566 \cdot 0.655 \cong 0.004$. A rise in the level of per capita income increases the ability to save and hence investment in both physical as well as human capital. ${ }^{11}$ The magnitude of this divergence effect is considerable. It is as large as the divergence mechanism resulting from an increase in the investment rate and nearly as large as the conditional convergence mechanism described above.

10. It should be noted that other studies find even higher values for this coefficient (e. g. Barro and Sala-I-MarTin, 1995, Chapter 12).

11. It should be noted that the human-capital proxy used here is a measure for the stock of human capital rather than a measure for the investment in human capital (Barro and LEE, 1993, Section 3). 
In summary, a 1 per cent increase in the average level of per capita income over the sample period is estimated to increase the average annual growth rate of per capita income by 1.1 percentage points on average; the extremely fragile divergence mechanism due to $\bar{n}$ has been excluded. This overall divergence effect is quantitatively more important than the convergence effect which results from a rise in the initial level of per capita income. As a consequence, the consideration of the endogenous variation of the control variables implies that the data support conditional $\beta$-divergence instead of conditional $\beta$ convergence, i. e. the growth dynamics seem to be characterised by unconditional as well as conditional $\beta$-divergence. This interpretation sharply contrasts with the conditional convergence results which state that the growth rate of per capita income falls along the transition to the balanced-growth equilibrium. However, this finding has to be interpreted carefully because of the following reasons: (i) The convergence regression only includes a restricted number of control variables. LEVINE and RENELT (1992) analyse the robustness of the partial correlations within the cross-sectional convergence regression framework and find that most control variables are not robust to changes in the set of control variables. (ii) The only 'convergence mechanism' which appears to be statistically significant in the sense that both components are highly significant is $C M_{\bar{i}}$. With respect to $\bar{g}, \bar{b}$, and $\bar{h}$ the mechanisms appear statistically fragile because the partial correlations with the growth rate are not significant at usual significance levels. However, because multicollinearity is likely to be present within cross-country growth regressions the standard deviations appear to be biased upwards. As a result, the coefficients could be judged as being insignificant although they might be significant (MANKIW, 1995). ${ }^{12}$ (iii) The restricted data availability inevitably introduces a sample-selection bias because the availability of data is typically correlated with the level of economic development.

\section{SUMMARY AND CONCLUSION}

Several influential development and growth theories stressed the notion that, from a theoretical point of view, 'poor' countries are expected to catch up with 'rich' countries. At least two basic economic mechanisms have been discussed in support of this view: (i) Diminishing returns to the factors that can be accumulated cause the growth rate of per capita income to fall in the course of economic development; the neoclassical convergence mechanism. (ii) According to the advantages-of-backwardness hypothesis (GERSCHENKRON, 1962), 'poor' countries should be able to exploit the opportunity to imitate technologies which have been developed elsewhere. Consequently, 'poor' countries are expected

12. Multicollinearity is probably present because of two reasons: (i) the endogenous variation of the control variables with per capita income probably shows up as a correlation between the averages of the control variables with the initial level of per capita income for a cross-section of countries. (ii) The second reason for multicollinearity among a subset of the control variables simply is that "As a rough approximation, those countries that do things right do most things right, and those countries that do things wrong do most things wrong." MANKIW (1995, p. 304). 
to catch up with 'rich' countries; the technological catching-up mechanism (ABRAMOVITZ, 1986). However, advocates of the endogenous growth theory argued convincingly that the convergence hypothesis has to be rejected on empirical grounds (ROMER, 1986, Section III). The advocates of the neoclassical growth theory forcefully argued in response that the neoclassical model does imply conditional convergence instead of unconditional convergence (Barro, 1991 and MANKIW, RoMER, and WeIL, 1992). According to this view, the balanced-growth equilibrium of each country is determined by a set of country-specific variables, the control variables, and the growth rate of per capita income is inversely related to the distance between an economy's current position and its balanced-growth equilibrium. Provided that the balanced-growth path is reached from below, the growth rate should fall during the transition process. However, this interpretation is crucially based on the assumption that control variables are exogenous with respect to economic development. If, on the other hand, the control variables are considered as being endogenous and hence vary in the course of economic development, then several distinct mechanisms of conditional convergence and divergence are possible. Theoretically, it is unclear a priori whether the net 'convergence mechanism' leads to conditional $\beta$-convergence or conditional $\beta$-divergence. The empirical results presented in the preceding section cast reasonable doubt on the view that empirical growth processes are characterised by conditional $\beta$-convergence.

\section{REFERENCES}

Abramovitz, M. (1986), Catching Up, Forging Ahead, and Falling Behind, Journal of Economic History, Vol. XLVI, 385-406.

Banks, A.S. (1997), Cross-National Time-Series Data Archive, Center for Social Analysis, State University of New York at Binghamton, Binghamton, New York.

BARro, R.J. (1991), Economic Growth in a Cross-Section of Countries, Quarterly Journal of Economics, Vol. 106, 407-443.

BARro, R.J. and J.-W. LeE (1993), International Comparisons of Educational Attainment, Journal of Monetary Economics, Vol. 32, 363-394.

Barro, R.J. and J.-W. Lee (1994), Data Set for a Panel of 138 Countries, Manuscript, Harvard University.

Barro, R.J. and X.X. Sala-I-Martin (1992), Convergence, Journal of Political Economy, Vol. 100, 223-251.

Barro, R.J. and X.X. Sala-I-Martin (1995), Economic Growth, McGraw Hill, New York.

BECKer, G.S. AND R.J. BARRo (1988), A Reformulation of the Economic Theory of Fertility, Quarterly Journal of Economics, Vol. 103, 1-25.

Becker, G.S., K.M. Murphy, and R. Tamura (1990), Human Capital, Fertility, and Economic Growth, Journal of Political Economy, Vol. 98, S12-S37. 
BонL, M. T. (1998), Konvergenz westdeutscher Regionen? Neue empirische Ergebnisse auf der Basis von Panel-Einheitswurzeltests, Konjunkturpolitik, Vol. 44, 82-99.

Caselli, F. , G. Esquivel, and F. Lefort (1996), Reopening the Convergence Debate: A New Look at Cross-Country Growth Empirics, Journal of Economic Growth, Vol. 1, $363-389$.

Chо, D. (1996), An Alternative Interpretation of the Conditional Convergence Results, Journal of Money, Credit and Banking, Vol. 28, 669-681.

Cohen, D. (1992), Tests of the 'Convergence Hypothesis': A Critical Note, CEPR Discussion Paper, No. 691.

De La Fuente, A. (1997), The Empirics of Growth and Convergence: A Selective Review, Journal of Economic Dynamics and Control, Vol. 21, 23-73.

Durlauf, S.N. and D.T. Quah (1998), The New Empirics of Economic Growth, Centre for Economic Performance Discussion Paper, No. 384.

Easterly, W. and R. Levine (1997), Africa's Growth Tragedy: Policies and Ethnic Divisions, Quarterly Journal of Economics, Vol. CXII, 1203-1250.

Gerschenkron, A. (1962), Economic Backwardness in Historical Perspective, Bert F. Hoselitz (ed.), The Progress of Underdeveloped Areas, University of Chicago Press, Chicago, 3-29.

Islam, N. (1995), Growth Empirics: A Panel Data Approach, Quarterly Journal of Economics, Vol. CX, 1127-1170.

Klenow, P. and A. Rodríguez-Clare (1997), Economic Growth: A Review Essay, Journal of Monetary Economics, Vol. 40, 597-617.

Kormendi, R.C. and P. G. Meguire (1985), Macroeconomic Determinants of Economic Growth: Cross-Country Evidence, Journal of Monetary Economics, Vol. 16, 141-163.

Levine, R. and D. Renelt (1992), A Sensitivity Analysis of Cross-Country Growth Regressions, American Economic Review, Vol. 82, 942-963.

De Long, B.J. (1988), Productivity Growth, Convergence, and Welfare: Comment, American Economic Review, Vol. 78, 1138-1154.

Mankiw, G. N. (1995), The Growth of Nations, Brookings Papers on Economic Activity, $1 / 95,275-326$.

Mankiw, G.N., D. Romer, and D.N. Weil (1992), A Contribution to the Empirics of Economic Growth, The Quarterly Journal of Economics, May, 407-437.

Pritchett, L. (1996), Forget Convergence: Divergence Past, Present, and Future, Finance and Development, Vol. 33, 40-43.

Romer, D. (1996), Advanced Macroeconomics, McGraw-Hill, New York.

Romer, P.M. (1986), Increasing Returns and Long-Run Growth, Journal of Political Economy, Vol. 94, 1002-1037.

Summers, R. and A. Heston (1988), A New Set of International Comparisons of Real Product and Price Levels Estimate for 130 Countries 1950-1985, Review of Income and Wealth, Vol. 34, 1-25.

Summers, R. and A. Heston (1999), The Penn World Table Mark 5.6; available e. g. at: http://arcadia.chass.utoronto.ca/pwt/. 
Temple, J. (1998), Equipment Investment and the Solow Model, Oxford Economic Papers, Vol. 50, 39-62.

Temple, J. (1999), The New Growth Evidence, Journal of Economic Literature, forthcoming.

WORLD BANK (1998), World Development Indicators, World Bank, Washington.

\section{SUMMARY}

The method of cross-sectional conditional convergence regression is crucially based on the concept of exogenous control variables. However, there are strong theoretical arguments and solid empirical support for the view that at least a subset of the control variables varies systematically in the course of economic development. In addition to econometric issues, the explicit consideration of endogenous control variables affects the theoretical interpretation of the conditional convergence results. Accordingly, the variation of some of the control variables with the level and the growth rate of per capita income contains important information about the transition to the balanced-growth equilibrium rather than information about the balanced-growth equilibrium itself.

\section{ZUSAMMENFASSUNG}

Die Methode der querschnittsanalytischen bedingten Konvergenzregression beruht wesentlich auf der Prämisse konstanter Kontrollvariablen. Es gibt allerdings starke theoretische Argumente und stichhaltige empirische Hinweise darauf, daß die Kontrollvariablen im Zuge der ökonomischen Entwicklung systematisch variieren. Neben ökonometrischen Aspekten beeinflußt die explizite Berïcksichtigung endogener Kontrollvariablen vor allem die theoretische Interpretation der Ergebnisse von bedingten Konvergenzregressionen. Die Variation einiger Kontrollvariablen mit dem Niveau und der Wachstumsrate des Pro-Kopf-Einkommens enthält demnach wichtige Informationen über den Anpassungsprozeß anstatt Informationen über das Wachstumsgleichgewicht.

\section{RESUME}

La méthode de la régression de convergence conditionnelle en coupe se base essentiellement sur la prémisse de variables de contrôle constantes. Il existe cependant d'importants arguments théoriques et de solides résultats empiriques indiquant que les variables de contrôle varient systématiquement au cours du développement économique. Outre les aspects économiques, la prise en compte explicite de variables de contrôle endogènes influe surtout sur l'interprétation théorique des résultats de régressions de convergence conditionnelles. 
La variation de quelques variables de contrôle en fonction du niveau et du taux de croissance du revenu par tête contient plutôt des informations importantes sur le processus d'adaptation que sur l'équilibre de croissance. 